\title{
Optyka adaptywna - nowa technologia w diagnostyce obrazowej
}

\author{
Adaptive optics: a new technology in diagnostic imaging
}

Jaromir Wasyluk ${ }^{1,2}$, Ilona Kaczmarek ${ }^{1}$,
Małgorzata Myślińska' ${ }^{1}$, Marta Dubisz

'Klinika Okulistyki, p.o. Kierownika Kliniki: dr n. med. Jaromir Wasyluk

${ }^{2}$ Centrum Okulistyczne OPTIMUM w Warszawie Kierownik medyczny: dr n. med. Małgorzata Krajewska

\section{STRESZCZENIE}

Technologia optyki adaptywnej (AO, adaptive optics) stała się w ostatnim czasie cennym narzędziem diagnostycznym w badaniach nad mikrostrukturą i funkcją siatkówki. Wykorzystując światło z zakresu bliskiej podczerwieni, kamera optyki adaptywnej umożliwia nieinwazyjne obrazowanie fotoreceptorów (głównie czopków), ściany i światła naczyń siatkówki, włókien nerwowych oraz struktur blaszki sitowej, które trudno uwidocznić za pomocą innych, stosowanych obecnie technik. Technologia AO może dostarczyć informacji o patologicznych zmianach w siatkówce, nawet gdy brakuje jakichkolwiek odchyleń od normy w obrazowych badaniach strukturalnych lub funkcjonalnych. Obecnie aparat $\mathrm{rtx}^{\mathrm{TM}}$ (Imagine Eyes, Francja) jest jedynym urządzeniem z kamera optyki adaptywnej dopuszczonym do badań okulistycznych w wielu krajach. W niniejszym artykule przedstawiamy krótki przegląd rozwoju technologii optyki adaptywnej oraz stale zmieniające się możliwości jej zastosowania w diagnostyce okulistycznej.

Słowa kluczowe: optyka adaptywna, fotoreceptory, obrazowanie siatkówki

\section{ABSTRACT}

The adaptive optics (AO) technology has become a valuable diagnostic tool in vision research for studying retinal microscopic structure and function. It is an infrared adaptive optics retinal camera that allows non-invasive visualization of cone photoreceptor cells, the retinal vessel wall and lumen diameter, nerve fibers, and structure of lamina cribrosa, that remain invisible with other current diagnostic techniques. The AO technology may provide information about the pathologic changes in the retina, even in the absence of structural or functional abnormalities in the current diagnostic imaging. The $\operatorname{rtx}^{\mathrm{TM}}$ (Imagine Eyes, France) is the only AO imaging device that has received regulatory clearance for ophthalmic examinations in multiple countries. In this article we present a brief overview of $\mathrm{AO}$ development, and its evolving range of applications in ophthalmic diagnostics.

Key words: adaptive optics, photoreceptors, retinal imaging 


\section{WSTĘP}

Metody obrazowania wnętrza gałki ocznej, a szczególnie siatkówki i nerwu wzrokowego, nieustannie się rozwijają, od czasu wynalezienia pierwszego wziernika bezpośredniego przez niemieckiego biofizyka Hermanna von Helmholtza w połowie XIX w. Kolejno wprowadzano do użytku oftalmoskopię pośrednią, umożliwiającą stereoskopową obserwację struktur oka, fundusfotografię klasyczną i cyfrową, a następnie metody oparte na konfokalnym (współogniskowym) skaningu laserowym. W tej ostatniej grupie należy wymienić przede wszystkim optyczną koherentną tomografię (OCT, optical coherence tomography) zapewniającą precyzję i wysoką rozdzielczość obrazu, która zrewolucjonizowała diagnostykę chorób siatkówki.

Przedstawiona w niniejszym opracowaniu technika z wykorzystaniem kamery z optyką adaptywną (AO, adaptive optics) idzie o krok dalej, pozwalając na obrazowanie dna oka z nieosiągalną do tej pory dokładnością. Założenia tej metody badawczej opracował już w latach 50. ubiegłego wieku amerykański astronom Horace Babcock, jednak z powodu istotnych zastosowań militarnych (satelity szpiegowskie i teleskopy) była ona niedostępna naukowcom cywilnym. Dopiero w 1990 r. armia amerykańska umożliwiła wykorzystanie optyki adaptywnej w nauce, a najważniejszym polem jej zastosowania stała się astronomia. Dzięki niezwykłej rozdzielczości oraz możliwości skorygowania zniekształceń powodowanych przez ośrodek (drgania górnych warstw atmosfery) poprzez teleskopy z optyką adaptywną udało się po raz pierwszy bezpośrednio zaobserwować planetę poza układem słonecznym, a także dokładnie zbadać Drogę Mleczną. AO wykorzystują obecnie wszystkie największe stacje teleskopowe świata. Kolejnym obszarem implementacji AO stała się okulistyka. Jedynym dostępnym obecnie aparatem do badań okulistycznych $\mathrm{z}$ kamerą optyki adaptywnej jest urządzenie $\mathrm{rtx}^{\mathrm{TM}}$ (Imagine Eyes, Francja) (ryc. 1).

Technologia AO wykorzystuje system lustra z plastyczną powierzchnią, którego kształt modelowany jest na bieżąco za pomocą czujników elektromagnetycznych. Zmiana kształtu zwierciadła pozwala na niwelację aberracji czoła fali (wavefront abberations) w czasie rzeczywistym, czyli już w trakcie przeprowadzania badania (ryc. 2). W ludzkim oku ośrodkami, które generują największe zniekształcenia obrazu (aberracje wyższego rzędu), są rogówka i soczewka. Źródłem światła w aparacie $r t x 1^{\mathrm{TM}}$ jest fala $\mathrm{z}$ diody pracującej w bliskiej podczerwieni (światło niekoherentne), a odbiornikiem obrazu - kamera CCD (charge-coupled device) wysokiej rozdzielczości. Zastosowane oprogramowanie (wciąż udoskonalane) pozwala na wiele interaktywnych pomiarów, m.in. gęstości rozmieszczenia fotoreceptorów czy grubości ścian i średnicy światła naczyń siatkówki.
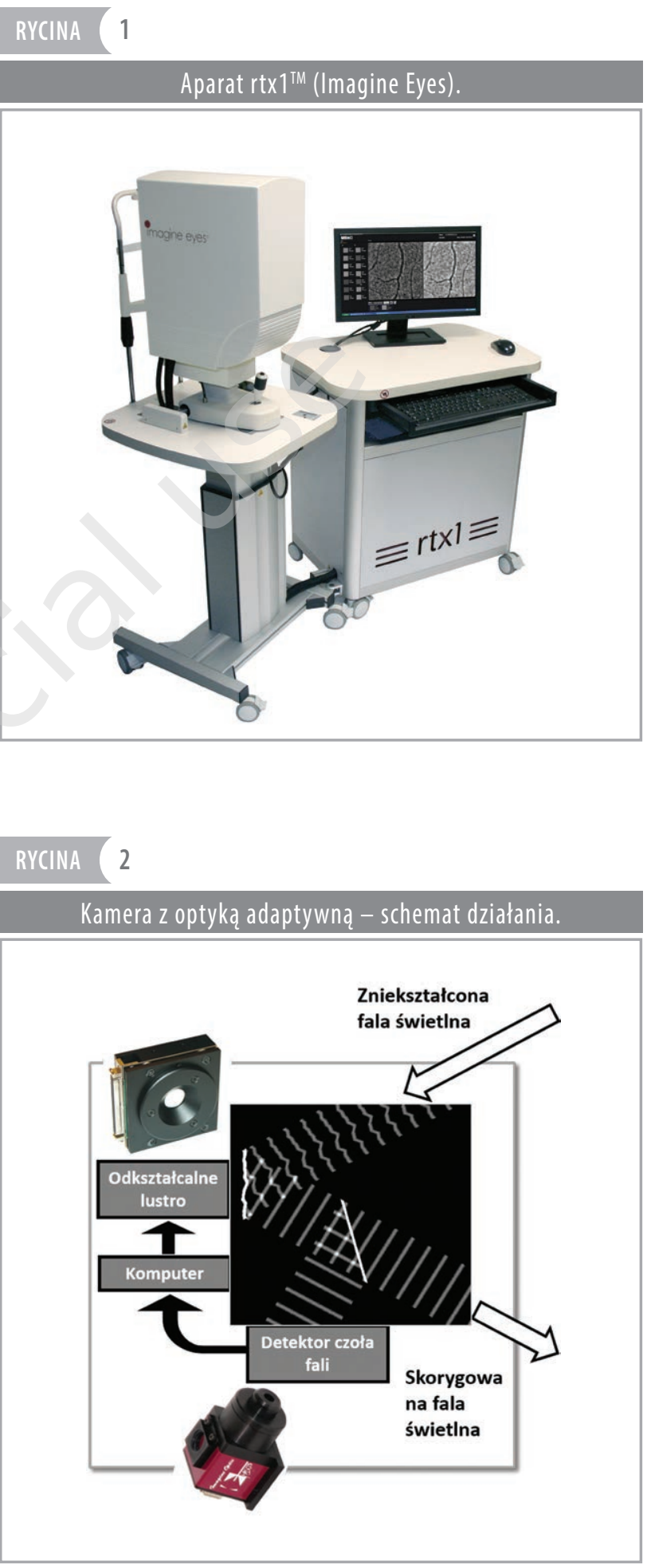

\section{TECHNIKA BADANIA}

Kamera optyki adaptywnej pozwala na uzyskiwanie obrazów dna oka w sposób bezkontaktowy i nieinwazyjny. Za pomocą aparatu rtx1 ${ }^{\mathrm{TM}}$, poprzez sterowanie głębią ostrości, możemy uzyskiwać obrazy fotoreceptorów, naczyń siatkówki oraz struktur tarczy nerwu wzrokowego z rozdzielczością rzędu 2-3 $\mu \mathrm{m}$ (ryc. 3-5). Badanie trwa od kilku do 
kilkunastu minut, w zależności od wielkości badanego obszaru dna oka, doświadczenia badającego oraz współpracy $\mathrm{z}$ pacjentem. Czas akwizycji jednego obrazu to $4 \mathrm{~s}$.

\section{RYCINA 3}

Obraz fotoreceptorów w plamce uzyskany kamerą A0.

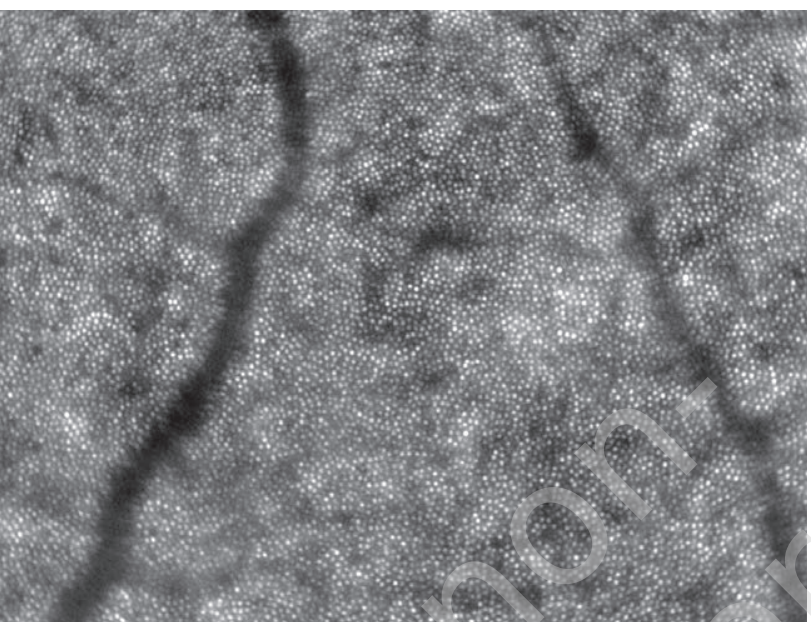

\section{RYCINA 4}

Interaktywny pomiar średnicy kapilary siatkówki.

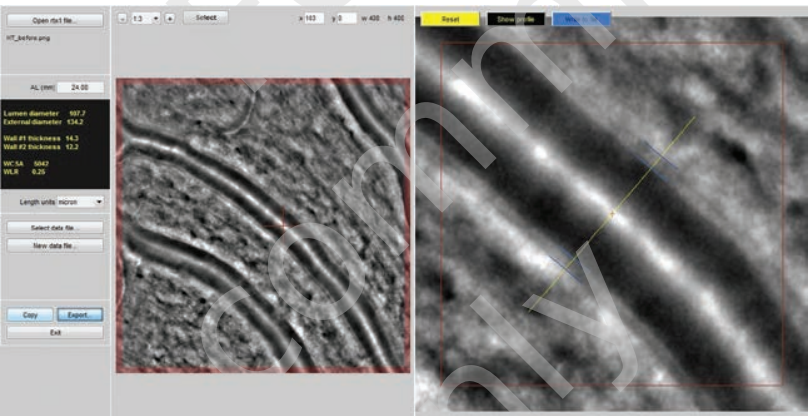

RYCINA 5
W trakcie badania źrenica powinna mieć szerokość min. $4 \mathrm{~mm}$ i na ogół zaleca się mydriazę lub przeprowadzanie pomiarów w półmroku. Badanie podatne jest również na błędy (artefakty), wynikające z zaburzeń przezierności ośrodków (zaćma, zmętnienia czy krwawienia do ciała szklistego), ruchów oka czy zmian chorobowych w samej siatkówce (krwotoki, obrzęki). Urządzenie ma wbudowany fiksator wewnętrzny, za pomocą którego można zobrazować obszar dna oka w zakresie $\pm 14,5^{\circ} \mathrm{w}$ poziomie oraz \pm $10,0^{\circ} \mathrm{w}$ pionie. Za pomocą fiksatora zewnętrznego obszar dostępny w badaniu zwiększa się do $+20,0^{\circ}$, co pozwala na uwidocznienie m.in. tarczy nerwu wzrokowego. Pojedyncze zdjęcie uzyskane kamerą optyki adaptywnej obejmuje obszar $4^{\circ} \times 4^{\circ}$ (ok. $1,2 \mathrm{~mm} \times 1,2 \mathrm{~mm}$, wartość zależna od długości osiowej gałki ocznej), który jest opisany współrzędnymi lokalizacyjnymi (współrzędna $0^{\circ}, 0^{\circ}$ dotyczy dołeczka). Zapisanie wartości współrzędnych pozwala na porównanie obrazów uzyskanych podczas kilku wizyt.

Oprogramowanie urządzenia wykrywa warstwę siatkówki o największej reflektywności, w większości przypadków jest nią nabłonek barwnikowy siatkówki, względem którego ustawia się ostrość kamery. Do oceny fotoreceptorów siatkówki służą m.in. mapa gęstości fotoreceptorów oraz mapa ich przestrzennego ułożenia (ryc. 6). Z kolei ocena struktury naczyń krwionośnych siatkówki jest możliwa m.in. na podstawie wartości współczynnika WLR (wall-to-lumen ratio), czyli stosunku grubości ściany naczynia do jego światła.

Blaszka sitowa na różnych poziomach skanowania.
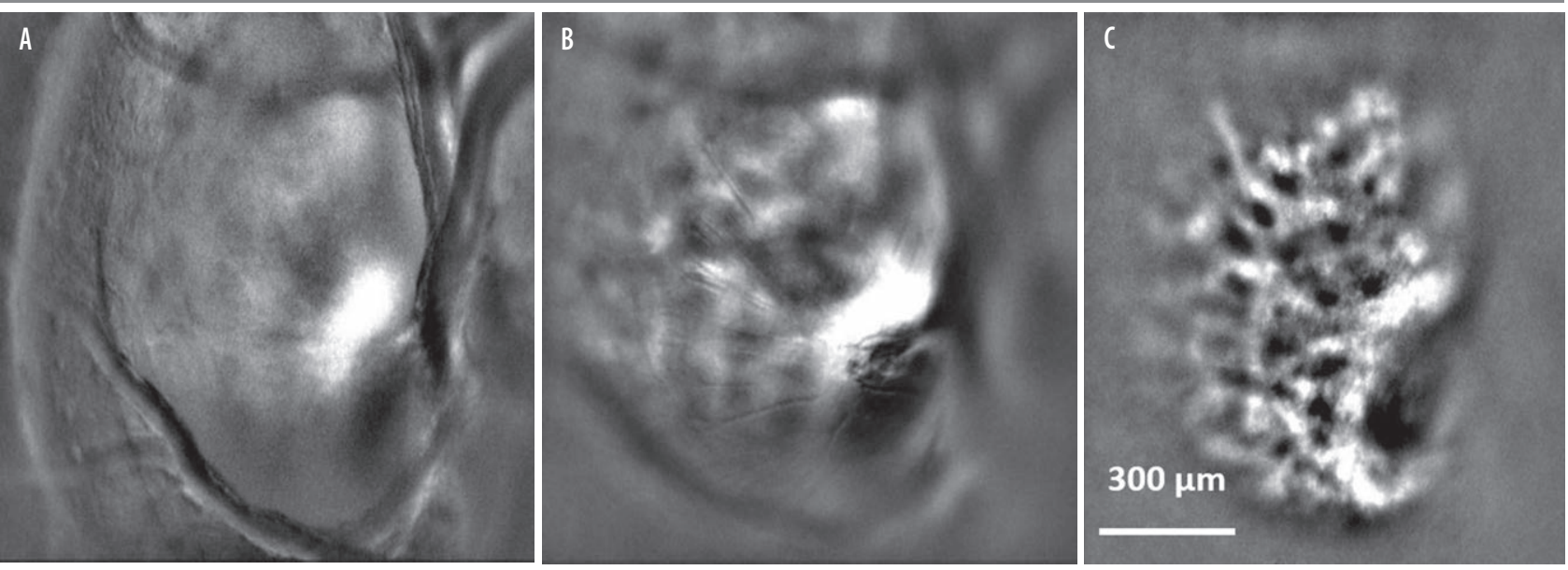


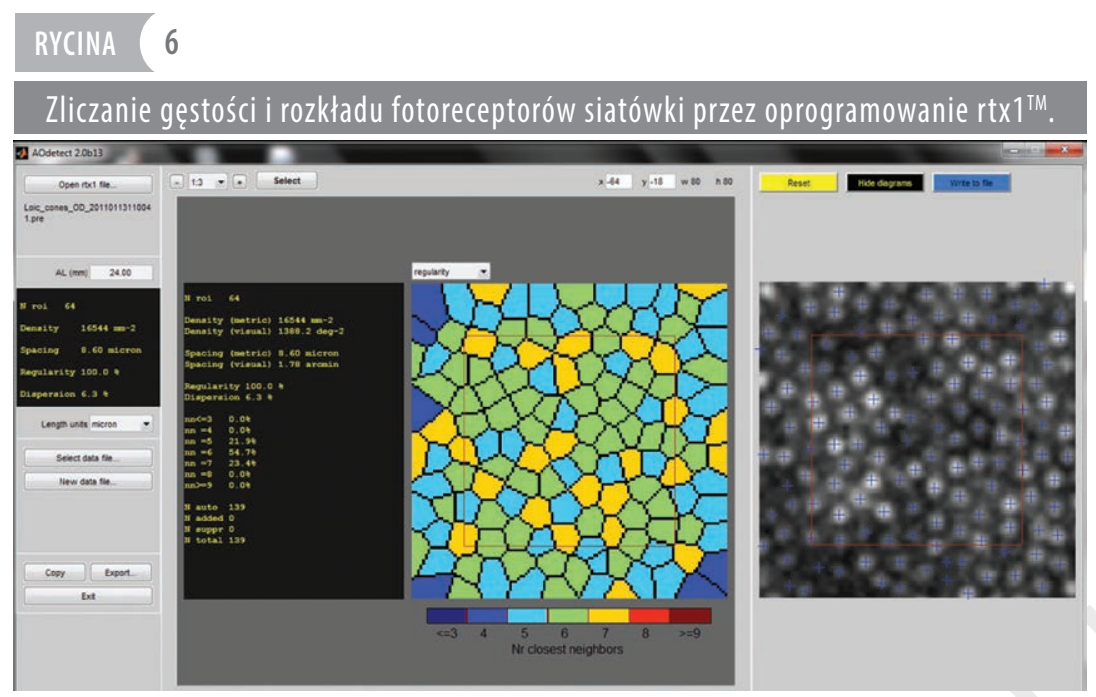

\section{ZASTOSOWANIE OPTYKI ADAPTYWNEJ W OKULISTYCE}

W Klinice Okulistyki WIML wykorzystywana jest kamera z optyką adaptywną, której zakup sfinansowany został ze środków grantu klinicznego Ministerstwa Obrony Narodowej (290/18/DA). Badani są m.in. piloci i kandydaci na pilotów wojskowych w celu uwidocznienia u nich niezdiagnozowanych zmian zwyrodnieniowych siatkówki czy uszkodzeń czynnikami fizycznymi powstałych w czasie pełnienia służby. Dotychczas przeprowadzone w wielu krajach badania $\mathrm{z}$ wykorzystaniem aparatu rtx1 ${ }^{\mathrm{TM}}$ dostarczają informacji pomocnych w diagnostyce i ocenie efektów leczenia poniższych chorób okulistycznych [1-25]:

- retinopatii cukrzycowej

- retinopatii nadciśnieniowej

- zapalenia naczyń siatkówki

- jaskry

- zwyrodnienia plamki żółtej związanego z wiekiem

- dystrofii siatkówki i naczyniówki

- retinopatii polekowych oraz uszkodzeń siatkówki na tle działania czynników fizycznych.

Optyka adaptywna wydaje się szczególnie cennym narzędziem diagnostycznym na wczesnym etapie rozwoju retinopatii cukrzycowej. Lombardo i wsp., wykorzystując aparat rtx1 $1^{\mathrm{TM}}$, wykazali zanik czopków w okołodołkowym obszarze siatkówki u pacjentów z rozpoznaną cukrzycą i jednocześnie prawidłowym obrazem dna oka [1]. Z kolei Zaleska-Żmijewska i wsp., po wykonaniu badań kamerą AO, opisali zmiany struktury naczyń krwionośnych u pacjentów z nieprawidłową tolerancją glukozy, bez rozpoznanej cukrzycy [2]. Ponadto wykazali oni istotną statystycznie korelację pomiędzy wartością współczynnika WLR a poziomem cholesterolu całkowitego i wskaźnikiem BMI (body mass index). Stopniowe zmniejszanie gęstości czopków wraz ze wzrostem stopnia zaawansowania retinopatii cukrzycowej opisali Soliman i wsp. [3].
Możliwość pomiaru światła naczyń siatkówki w warunkach in vivo sprawia, że AO stosowana jest do oceny zmian struktury tych naczyń w odpowiedzi na wzrost wartości ciśnienia tętniczego krwi (ryc. 7). Koch i wsp. wykazali związek pomiędzy wartością współczynnika WLR a średnim ciśnieniem tętniczym oraz wiekiem pacjenta [4]. Monitorowanie wartości współczynnika WLR w naczyniach siatkówki może więc służyć do oceny skuteczności leczenia hipotensyjnego u pacjentów z nadciśnieniem tętniczym [5]. W przypadku zapalenia naczyń siatkówki AO pozwala na zobrazowanie niewidocznych w angiografii fluoresceinowej nacieków zapalnych w ścianie naczyń siatkówki $[6,7]$.

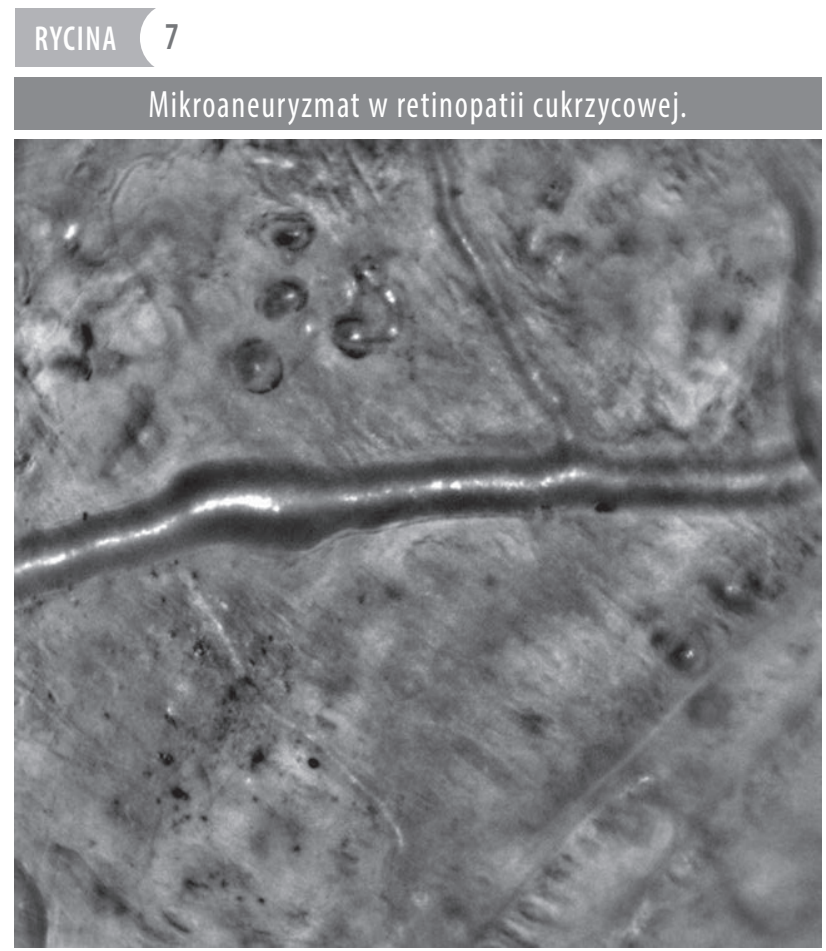


Dzięki precyzyjnemu obrazowaniu struktur blaszki sitowej na różnych głębokościach $\mathrm{AO}$ stosowana jest również do oceny zmian w budowie blaszki sitowej u pacjentów z jaskrą. Zwillinger i wsp., po przeprowadzeniu badań z wykorzystaniem AO, opisali owalizację porów blaszki sitowej u 78\% pacjentów z jaskrą pierwotną otwartego kąta i odpowiednio 19,4\% w grupie kontrolnej osób niechorujących na jaskrę [8]. U pacjentów z rozpoznaną suchą postacią zwyrodnienia plamki związanego z wiekiem (AMD, age-related macular degeneration) technologia AO umożliwia dokładną ocenę progresji choroby [9]. Gocho i wsp. opisali progresję zaniku geograficznego w plamce już po 2 tygodniach obserwacji pacjenta z suchą postacią AMD [10]. AO stosowana jest również w badaniach nad wykorzystaniem komórek macierzystych w leczeniu postaci wysiękowej AMD [11, 12].

Po uzyskaniu obrazu fotoreceptorów siatkówki za pomocą kamery AO otrzymujemy m.in. mapę gęstości fotoreceptorów, mapę ich przestrzennego ułożenia oraz mapę pleomorfizmu fotoreceptorów. Zastosowane statystyki opisowe pozwalają na wykorzystanie tych map w diagnostyce dystrofii dna oka, takich jak: zwyrodnienie barwnikowe siatkówki, zespół Ushera, choroba Stargardta (ryc. 8), dystrofia czopków, achromatopsja, choroba Besta, dystrofia Biettiego, chorioideremia, i innych [13-19].

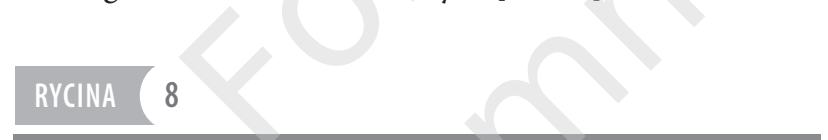

\section{Obraz fotoreceptorów w dystrofii Stargardta.}
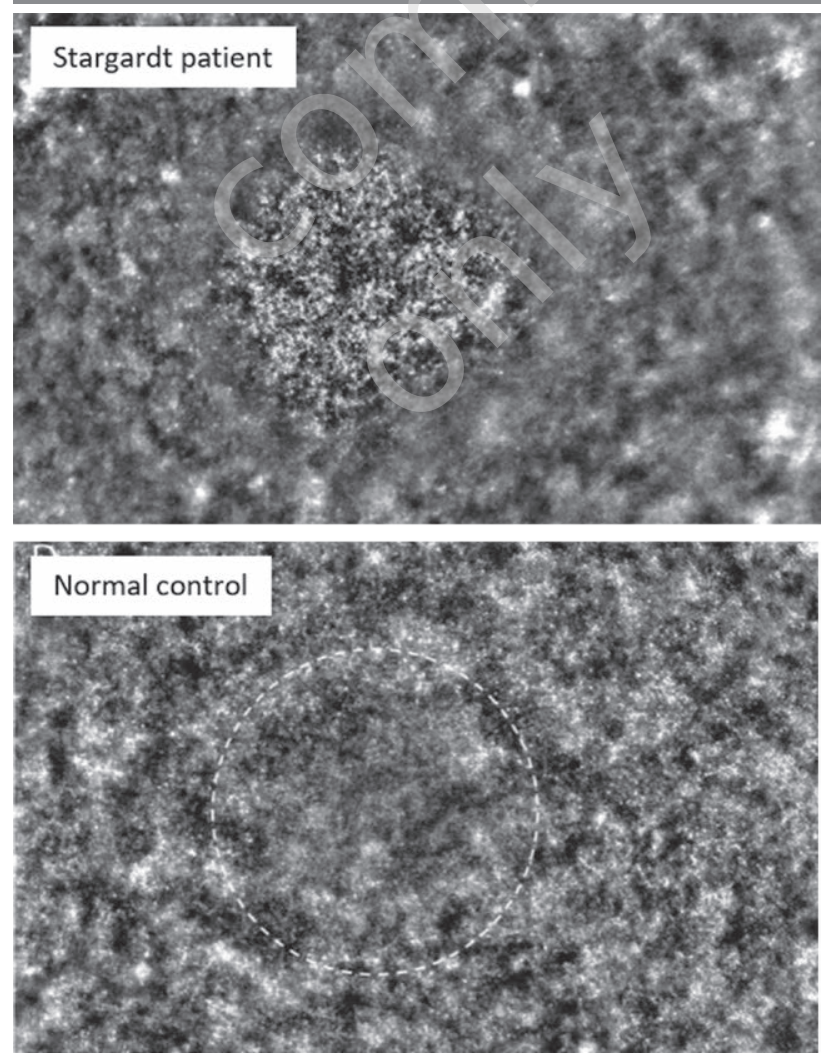

Możliwość obrazowania i analizy pojedynczych fotoreceptorów siatkówki sprawia, że optyka adaptywna może być również stosowana do oceny stopnia regeneracji fotoreceptorów w przebiegu zespołu licznych znikających białych punktów (MEWDS, multiple evanescent white dot syndrome) oraz po operacjach naprawczych odwarstwionej siatkówki [20, 21]. Ponadto AO znajduje zastosowanie w badaniach wpływu toksyczności leków na siatkówkę. Debellemanière i wsp., wykorzystując aparat rtx1 $1^{\mathrm{TM}}$, przeanalizowali gęstość czopków u 23 pacjentów przyjmujących hydroksychlorochinę, u których nie występowały kliniczne objawy makulopatii [22]. W badaniu wykazali zmniejszenie gęstości czopków (w obszarze okołodołkowym) wskutek odkładania w siatkówce złogów hydroksychlorochiny. Badanie fotoreceptorów za pomocą AO znajduje zastosowanie także w analizie zmian siatkówkowych występujących po stosowaniu niektórych typów substancji psychoaktywnych wziewnych [23] lub dożylnych (retinopatia talkowa) [24], a także w uszkodzeniach powstałych na skutek działania czynników fizycznych, jak w retinopatii słonecznej [25].

\section{PODSUMOWANIE}

Kamera optyki adaptywnej aparatu $r t x 1^{\mathrm{TM}}$ jest obecnie jedynym urządzeniem, które pozwala zobrazować i ocenić strukturę pojedynczych fotoreceptorów siatkówki. Ponadto umożliwia badanie morfologii blaszki sitowej na różnych poziomach głębokości oraz pomiary średnicy światła i grubości ścian naczyń krwionośnych siatkówki, a także włókien nerwowych. Największą zaletę optyki adaptywnej stanowi możliwość wykrywania patologicznych zmian dna oka na bardzo wczesnym etapie ich rozwoju, gdy niemożliwe jest ich rozpoznanie obecnie stosowanymi technikami obrazowania dna oka. To szczególnie ważne w przypadku dystrofii wrodzonych, w których prognozowanie co do widzenia jest trudne, oraz w retinopatii cukrzycowej, która jako powikłanie okulistyczne tej choroby cywilizacyjnej stanowi pierwszą przyczynę utraty widzenia w grupie pacjentów czynnych zawodowo.

Źródto rycin: Wszystkie ryciny są własnościa firmy Imagine Eyes $i$ zostaty opublikowane za jej zgoda. 


\author{
ADRES DO KORESPONDENCJI \\ dr n. med. Jaromir Wasyluk \\ Klinika Okulistyki, \\ Wojskowy Instytut Medycyny Lotniczej \\ 01-755 Warszawa, ul. Krasińskiego 54/56 \\ e-mail: jwasyluk@wiml.waw.pl
}

ORCID:

Jaromir Wasyluk - ID - http://orcid.org/0000-0002-0080-6050

\section{Piśmiennictwo}

1. Lombardo M, Parravano $M$, Serrao $S$ et al. Investigation of adaptive optics imaging biomarkers for detecting pathological changes of the cone mosaic in patients with type 1 diabetes mellitus. PLoS One. 2016; 11(3): e0151380.

2. Zaleska-Żmijewska A, Piątkiewicz P, Śmigielska B et al. Retinal photoreceptors and microvascular changes in prediabetes measured with adaptive optics $\left(r t \times 1^{T M}\right)$ : a case-control study. J Diabetes Res. 2017: 1-9.

3. Soliman MK, Sadiq MA, Agarwal A et al. High-Resolution Imaging of Parafoveal Cones in Different Stages of Diabetic Retinopathy Using Adaptive Optics Fundus Camera. PLoS One. 2016; 11(4): e0152788.

4. Koch E, Rosenbaum D, Brolly A et al. Morphometric analysis of small arteries in the human retina using adaptive optics imaging: relationship with blood pressure and focal vascular changes. J Hypertens. 2014; 32(4): 890-8.

5. Rosenbaum D, Mattina A, Koch E et al. Effects of age, blood pressure and antihypertensive treatments on retinal arterioles remodeling assessed by adaptive optics. J Hypertens. 2016; 34(6): 1115-22.

6. Errera MH, Laguarrigue M, Rossant F et al. High-Resolution Imaging of Retinal Vasculitis by Flood Illumination Adaptive Optics Ophthalmoscopy: A Follow-up Study. Ocul Immunol Inflamm. 2019; 1: 1-10.

7. Errera MH, Coisy S, Fardeau C et al. Retinal vasculitis imaging by adaptive optics. Ophthalmology. 2014; 121(6): 1311-2.e2.

8. Zwillinger S, Paques M, Safran B et al. In vivo characterization of lamina cribrosa pore morphology in primary open-angle glaucoma. J Fr Ophtalmol. 2016; 39(3): 265-71.

9. Paques M, Meimon S, Rossant F et al. Adaptive optics ophthalmoscopy: Application to age-related macular degeneration and vascular diseases. Prog Retin Eye Res. 2018; 66: 1-16.

10. Gocho K, Sarda V, Falah S et al. Adaptive optics imaging of geographic atrophy. Invest Ophthalmol Vis Sci. 2013; 54(5): 3673-80.

11. Takagi S, Mandai M, Gocho K et al. Evaluation of Transplanted Autologous Induced Pluripotent Stem Cell-Derived Retinal Pigment Epithelium in Exudative Age-Related Macular Degeneration. Ophthalmol Retina. 2019; 3(10): 850-9.

12. da Cruz L, Fynes K, Georgiadis $\mathrm{O}$ et al. Phase 1 clinical study of an embryonic stem cell-derived retinal pigment epithelium patch in age-related macular degeneration. Nat Biotechnol. 2018; 36(4): 328-37.

13. Tojo N, Nakamura T, Fuchizawa C et al. Adaptive optics fundus images of cone photoreceptors in the macula of patients with retinitis pigmentosa. Clin Ophthalmol. 2013; 7: 203-10.

14. Pang CE, Suqin Y, Sherman J et al. New insights into Stargardt disease with multimodal imaging. Ophthalmic Surg Lasers Imaging Retina. 2015; 46(2): 257-61.

15. Gocho K, Kameya S, Akeo K et al. High-Resolution Imaging of Patients with Bietti Crystalline Dystrophy with CYP4V2 Mutation. J Ophthalmol. 2014; 2014: 283603.

16. Sun LW, Johnson RD, Langlo CS et al. Assessing Photoreceptor Structure in Retinitis Pigmentosa and Usher Syndrome. Invest Ophthalmol Vis Sci. 2016; 57(6): 2428-42.

17. Kominami A, Ueno S, Kominami T et al. Case of cone dystrophy with normal fundus appearance associated with biallelic POC1B variants. Ophthalmic Genet. 2018; 39(2): 255-62.

18. Georgiou M, Kalitzeos A, Patterson EJ et al. Adaptive optics imaging of inherited retinal diseases. Br J Ophthalmol. 2018; 102 (8): $1028-35$.

19. Georgiou M, Litts KM, Kalitzeos A et al. Adaptive Optics Retinal Imaging in CNGA3-Associated Achromatopsia: Retinal Characterization, Interocular Symmetry, and Intrafamilial Variability. Invest Ophthalmol Vis Sci. 2019; 60(1): 383-96.

20. Boretsky A, Mirza S, Khan F et al. High-resolution multimodal imaging of multiple evanescent white dot syndrome. Ophthalmic Surg Lasers Imaging Retina. 2013; 44(3): 296-300.

21. Ra E, Ito Y, Kawano K et al. Regeneration of Photoreceptor Outer Segments After Scleral Buckling Surgery for Rhegmatogenous Retinal Detachment. Am J Ophthalmol. 2017; 177: 17-26.

22. Debellemanière $G$, Flores $M$, Tumahai $P$ et al. Assessment of parafoveal cone density in patients taking hydroxychloroquine in the absence of clinically documented retinal toxicity. Acta Ophthalmol. 2015; 93(7): e534-40. 
23. Audo I, Sanharawi ME, Vignal-Clermont C et al. Foveal Damage in Habitual Poppers Users. Arch Ophthalmol. 2011; 129(6): $703-8$. https://doi.org/10.1001/archophthalmol 2011.6. Epub 2011.

24. Soliman MK, Sarwar S, Hanout M et al. High-resolution adaptive optics findings in talc retinopathy Int J Retina Vitreous. $2015 ; 1: 10$.

25. Wu CY, Jansen ME, Andrade J. Acute Solar Retinopathy Imaged with Adaptive Optics, Optical Coherence Tomography Angiography, and En Face Optical Coherence Tomography. JAMA Ophthalmol. 2018; 136(1): 82-5.

Wkład autorów:

Wszyscy autorzy w równym stopniu przyczynili się do powstania artykułu.

Konflikt interesów:

Nie wystęuje.

Finansowanie:

Nie występuje.

Etyka:

Treści przedstawione w artykule są zgodne z zasadami Deklaracji Helsińskiej,

dyrektywami EU oraz ujednoliconymi wymaganiami dla czasopism biomedycznych.
Authors' contributions:

All authors contributed equally to the article.

Conflict of interest:

None.

Financial support:

None.

Ethics:

The content presented in the article complies with the principles of the Helsinki Declaration, EU directives and harmonized requirements for biomedical journals. 